This item was submitted to Loughborough's Research Repository by the author.

Items in Figshare are protected by copyright, with all rights reserved, unless otherwise indicated.

\title{
The uses and abuses of rapid bioluminescence-based ATP assays
}

PLEASE CITE THE PUBLISHED VERSION

http://dx.doi.org/10.1016/j.jheh.2012.03.009

PUBLISHER

(c) Elsevier

VERSION

AM (Accepted Manuscript)

LICENCE

CC BY-NC-ND 4.0

REPOSITORY RECORD

Shama, Gilbert, and Danish J. Malik. 2012. "The Uses and Abuses of Rapid Bioluminescence-based ATP Assays". figshare. https://hdl.handle.net/2134/11028. 
This item was submitted to Loughborough's Institutional Repository (https://dspace.lboro.ac.uk/) by the author and is made available under the following Creative Commons Licence conditions.

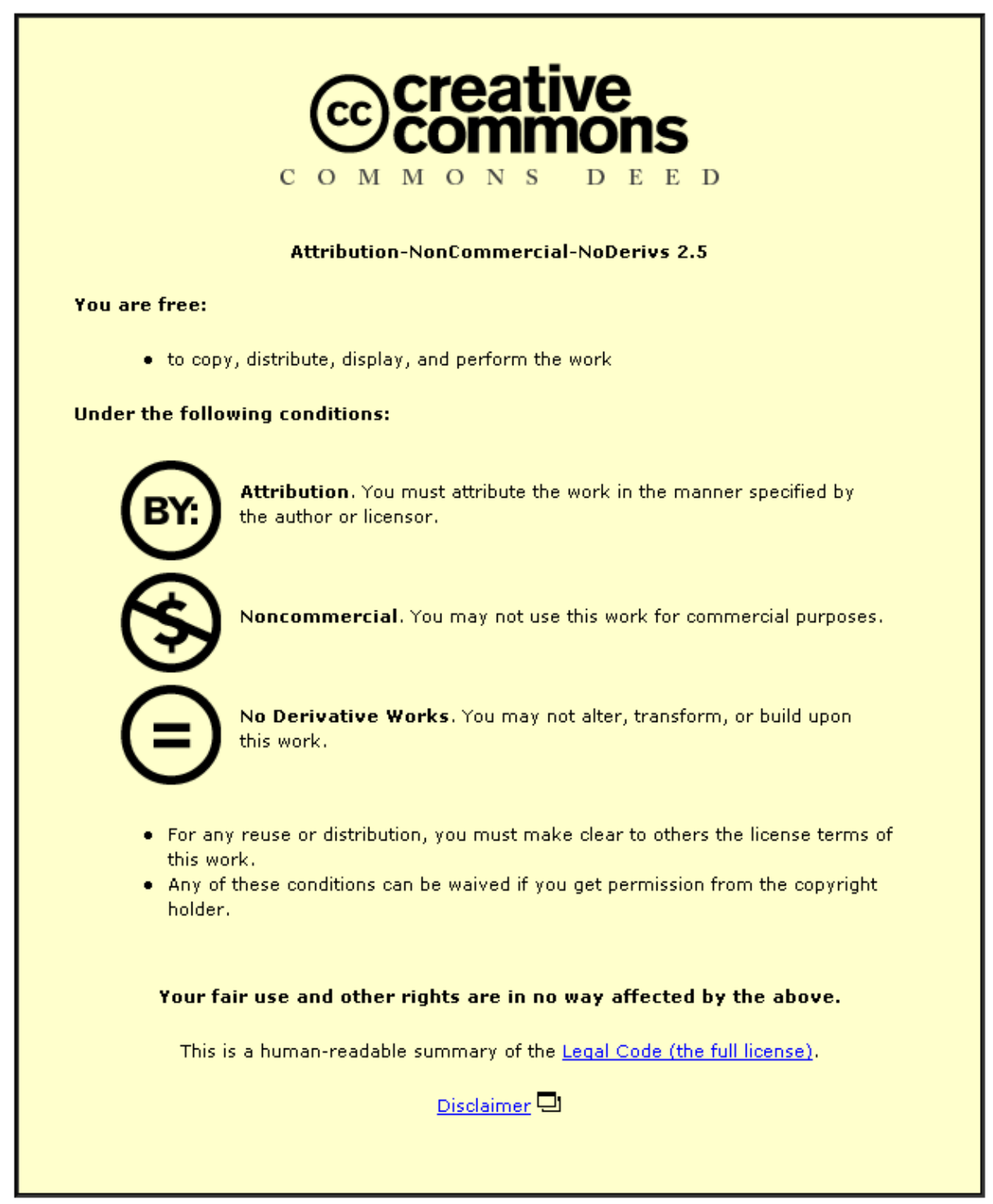

For the full text of this licence, please go to: http://creativecommons.org/licenses/by-nc-nd/2.5/ 
The Uses and Abuses of Rapid Bioluminescence-Based ATP Assays

\author{
G. Shama* and D. J. Malik
}

Department of Chemical Engineering, Loughborough University, Loughborough, LE11 3TU, United Kingdom

\title{
ABSTRACT
}

Bioluminescence-based ATP testing of solid surfaces has become well established in the food processing industry as part of general hazard analysis and critical control points (HACCP) measures. The rise in healthcare associated infections (HAIs) at the turn of the century focussed attention on the environment as a potential reservoir of the agents responsible for such infections. In response to the need for objective methods of assessing the efficiency of cleaning in healthcare establishments and for rapid methods for detecting the presence of the pathogens responsible for HAls, it was proposed that ATP testing of environmental surfaces be introduced. We examine the basis behind the assumptions inherent in these proposals. Intracellular ATP levels are shown to vary between microbial taxa and according to environmental conditions. Good correlations between microbial numbers and ATP levels have been obtained under certain specific conditions, but never within healthcare settings. Notwithstanding, ATP testing may still have a role in providing reassurance that cleaning regimes are being carried out satisfactorily. However, ATP results should not be interpreted as surrogate indicators for the presence of microbial pathogens.

Keywords: ATP Testing, Food Processing Industry, Healthcare, Hospital Acquired Infections, Hospital Cleaning *Corresponding Author E-mail Address G.Shama@Lboro.ac.uk (G.Shama) 


\section{Introduction}

Adenosine triphosphate (ATP) is the principal energy carrier for all living organisms. Irrespective of its source, all energy, whether from chemical oxidation or the capture of light, is transformed by living cells into ATP. It is in this form that cells expend the energy acquired for all processes that require it including biosynthesis, motility and various maintenance functions.

The occurrence of ATP in cells makes its detection symptomatic of the presence of living organisms. There are a number of ways of assaying ATP from environmental samples including for example high pressure liquid chromatography (Prevost et al., 1991), but in the current work attention will be confined to just one method bioluminescence based on the reaction of the enzyme luciferase - typically extracted from fireflies of the genus Photinus - with its substrate luciferin. In a survey of the development of research into bioluminescence, Fraga (2008) points out that whilst the topic had been the subject of scientific investigations since 1885 , it was W. D. McElroy who in 1947 first showed that the light emitted during the reaction was directly proportional to the amount of ATP added. McElroy went on to fully elucidate the reaction which is given below:-

$$
\begin{aligned}
\text { D-Luciferin }+ \text { ATP }+\mathrm{O}_{2} \underset{\mathrm{Mg}^{2+}}{\stackrel{\text { Luciferase }}{\longrightarrow} \text { Oxyluciferin }+\mathrm{AMP}} \\
+\mathrm{PP}_{\mathrm{i}}+\mathrm{CO}_{2}+\mathrm{hv}
\end{aligned}
$$

In the presence of oxygen and magnesium ions, luciferin is converted to oxyluciferin and ATP is converted to adenosine monophosphate (AMP) with the release of pyrophosphate and the emission of light in the wavelength range of 470 to $700 \mathrm{~nm}$ and peaking at $562 \mathrm{~nm}$. 
By the mid-1960s this reaction was being exploited to detect low levels of ATP initially with scintillation counters (Addanki, 1966) and later using photomultiplier tubes (Van Dyke et al., 1969). Since then all the reagents have become commercially available in pre-dispensed and easy to use kit form along with relatively low cost hand-held luminometers for the rapid determination of ATP on solid surfaces. In virtually all commercial kits the removal of ATP from surfaces is effected with swabs of which more will be said later.

In what follows, the impact that rapid methods of ATP testing have had in the food processing industries is described first. Next, consideration is given to the climate leading to proposals that rapid ATP testing could be used to reduce incidences of healthcare associated infections (HAIs). Following this is a survey of previously published work relating microbial number to ATP concentration, also included in this section is an account of how environmental factors can influence intracellular ATP content. Limitations inherent in bioluminescence-based testing of ATP are considered next. Finally, a critical assessment is presented of the potential role that rapid ATP testing could play in the healthcare sector.

\section{ATP Testing in the Food Processing Industry}

Hazard Analysis and Critical Control Points (HACCP)

The use of rapid ATP determination kits in the food industry has become widespread, and it is therefore appropriate to consider briefly the factors that led to its introduction. The use of such kits may be directly linked to the adoption within the food industry of a concept for systematically putting in place measures to ensure the production of foods in which all forms of potential contaminants have been reduced to acceptable levels. This concept is known as hazard analysis and critical control points (HACCP). 
It originally arose out of the need to safeguard multi-million dollar space exploration missions through the provision of foods to astronauts free from pathogenic microorganisms that were capable of causing food poisoning (Bauman, 1974). HACCP's appeal lies in its emphasis on preventing food contamination, and central to the concept is the notion that any food processing operation will have associated with it one or more steps at which control can be exerted - i.e. points at which an intervention can be applied to prevent or eliminate a food safety hazard or reduce it to an acceptable level. Such steps are known as critical control points (CCP).

To give an example; foods can become contaminated by contact with a surface that harbours micro-organisms (Perez-Rodriguez et al., 2008). A common CCP in a food processing operation is to ensure that surfaces with which a particular food may come into contact with are free from microbial contamination. In practice this would require the removal of any food adhering to surfaces by washing, as, if left on a surface such food could serve as a source of nutrients for micro-organisms present in the environment. The consequence of failing to remove food residues would be that micro-organisms would be able to proliferate at the surface and could then go on to contaminate food that subsequently came into contact with it. Washing of surfaces would generally be followed by the application of a suitable sanitizer to kill any residual microflora. The provisions of HACCP require that regular scheduled monitoring procedures be undertaken to ensure that critical control points remain 'under control'. Time series data may be collected for the CCPs to identify trends and highlight any unexpected variations indicating out of control events. This surveillance may adequately be achieved by conventional microbiological methods which would entail swabbing the surface followed by plating onto a suitably formulated agar. However, the disadvantage of this approach is that the agar plates 
have to be incubated for periods as long as 48 hours. Holding - that is, not releasing into the distribution chain - processed foods for such periods of time becomes costly in terms of warehouse space and is impractical for many other reasons too.

Because of the ease with which ATP determinations can now be carried out, they offer a convenient alternative to traditional microbial assays and it enables the presence of food residues on a surface to be detected within seconds (Seeger and Griffiths, 1994).

Equally important is the ability to act on the information provided by such tests in a timely manner and in such a way as to safeguard food processing (Poulis et al., 1993). To take a specific example, a high ATP reading at a specific location would indicate a failure in cleaning which would require an intervention i.e. a re-clean. All foods - whether of plant or animal origin - contain ATP, and microbial ATP generally represents only a relatively minor fraction of the total ATP that may be present at a particular surface in a food processing environment (Lundin, 2000).

\section{Interpreting ATP Measurements}

Surface ATP measurements following routine cleaning operations therefore provide an assessment of the overall levels of organic surface contamination. Such measurements provide an indication of the quality of cleaning, but should not be interpreted as a direct indicator of microbial surface contamination. ATP hygiene monitoring has been used in a variety of food processing environments including dairy processing (Bell et al., 1994) and brewing (Carrick et al., 2001) to name just two. Studies where both ATP assays and microbiological plate counts were carried out simultaneously have yielded a level of agreement of about $70 \%$ in categorising passes and failures after cleaning (Griffiths, 1996). Of the remaining $30 \%$ of 
samples that revealed variances between the two assays, the majority of cases yielded high ATP readings - indicating a failure in cleaning and sanitising procedures

- in combination with very low plate counts. This discrepancy may be explained by the presence of food residues due to inadequate cleaning that, whilst generating an ATP signal, were substantially free of micro-organisms. This study also revealed cases with high plate counts but with low ATP levels. Such false negative results are considered further below.

\section{Healthcare Associated Infections (HAls)}

The Crisis Posed by HAls

The suggestion that ATP testing might have a role to play in monitoring cleaning practices in the healthcare sector has an altogether different origin. The early to mid90s began to witness a rise in what became known as healthcare associated infections (HAIs). Incidences of HAls were particularly prevalent in Western countries, and their impact has since been documented both for individual countries - e.g. the United States (Jarvis, 2007), and also for entire regions e.g. the European Union (Pittet et al., 2005). These infections - typically contracted on hospital wards - were caused by bacteria that had acquired antibiotic resistance, in some measure at least, through poor prescription practices. A number of different bacteria have been implicated in HAls, but two of the most common were, and remain, methicillin resistant Staphylococcus aureus (MRSA) and Clostridium difficile. It has now become routine for national agencies charged with health protection and disease control to publish annual statistics on the rates of infection by causative agent, but those for England and Wales hold a particular significance in explaining how subsequent events came to unfold as will be shown below. 
By 2005, annual deaths in which MRSA was the principal, or associated cause in these two countries had peaked at just over 1,600 (ONS, 2011a). The corresponding peak for C. difficile occurred slightly later (ONS, 2011b) but accounted for some 8,000 deaths. Although apparently in decline, both remain the causes of significant numbers of deaths. Whilst justifiably provoking outrage by what were widely seen as avoidable deaths, these figures were seized upon in the UK by those seeking to make political capital from the situation. According to these critics the principal reason behind the mounting incidences of HAI was that the basic tenets of healthcare had been sacrificed in the pursuit of government-imposed targets for what has euphemistically been termed 'cost containment' (Griffith et al., 2000). One of the supposed casualties of such policies was hospital cleaning which was increasingly contracted out of the Health Service to independent commercial organisations that had had to bid for the contract. Inevitably the press became embroiled, and painted an image of 'dirty hospitals' that were the breeding ground of rampant 'superbugs' such as MRSA that even had nefarious motives ascribed to them (Washer \& Joffe, 2006). There were wistful references in the press to a 'golden age' of health services presided over by nursing matrons who were able to impose a regime founded on the good old fashioned virtues of cleanliness (Crawford et al., 2008). But of course there never was a golden age, and things had not changed significantly in over 50 years as an article in Time magazine makes clear (Anon., 1957). In the piece, a certain Dr Carl Walter expostulated, 'doctors rely too much on antibiotics, ignoring the fact that bacteria which defy the antibiotics stay around hospitals.' Even the article's headline - 'Dirty Hospitals?' - would have been instantly recognisable to a contemporary reader: plus ça change...... 
In 2007 the government stepped in with a much-heralded programme of 'deep cleaning' when it appeared that the UK National Health Service was in danger of losing public confidence (Department of Health, 2008). Amid the furore, a health minister made the pronouncement that the UK National Health Service had lessons it could learn about cleanliness from the food industry. It is a statement that has come to have significant impact as we will show.

Approximately a decade on from these events it is pertinent to consider just what 'lessons' the health sector has attempted to take from the food industry and view them in the wider context of what assumptions have been made either tacitly or consciously in attempting to transform cleaning and disinfection practices in the healthcare sector. Indeed, was the comparison between these two very different sectors even appropriate in the first place?

The Role of the Environment in HAls

The crisis in relation to HAls gave rise to a thorough investigation into the state of cleanliness in hospitals, and in particular how cleaning was assessed. Collins (1988) viewed cleaning as providing two functions that he termed 'non-microbiological' and 'microbiological'. The former had to do with improving or restoring appearance, the maintenance of function, and the prevention of deterioration. Whereas the latter involved reducing the numbers of micro-organisms and removing matter that would support their growth. These two functions are of course not completely independent. The state of cleanliness of healthcare establishments is largely based upon visual inspection, but a number of studies have since cast doubts on this as a meaningful objective measure (Griffith et al. 2000; Lewis et al. 2008). The focus on the cleanliness of healthcare environment and methods of how this might be achieved at 
a time of rising incidences of HAls implied the existence of a causal relationship; that is, that the environment served as a reservoir for the pathogens responsible for HAls, and that infection could occur directly from the environment.

However, the current 'zero tolerance' attitude to the presence of the causative agents of HAls (Jarvis, 2007) is not one that was always the prevailing point of view. This is revealed in the titles of articles published before rates of HAls began to rise steeply:- 'Multiresistant Staphylococcus aureus - A Suitable Case for Inactivity' (Lacey, 1987), 'Learning to live with MRSA' (Rahman, 1998) and 'MRSA in burns patients - why all the fuss?' (Reardon, et al.,1998). The article by Lacey (1987) is particularly worthy of note because in it he argued against measures that he saw as essentially leading to the 'persecution to extinction' of one such agent of HAI specifically MRSA. Although not in any way constituting the first shots in an attempt to rehabilitate a wronged or misunderstood micro-organism, he pointed out the dangers of fixation upon an individual micro-organism - one moreover that happens to be commensal in humans. He questioned whether consideration had been given to what would take its place if the task of eradicating it from the environment was ever accomplished.

There has been a significant shift of opinion since then and a number of workers now view the role of the environment as significant in the transmission of HAls (Boyce, 2007; Weber and Rutala, 2011). This view has partly been sustained by findings that show that pathogens are able to survive for extended periods of time in the environment (Kramer et al., 2006; Chaibenjawong and Foster, 2011). Some commentators (Dancer, 2008) have sought to stress the maintenance of a clean environment as crucial in controlling HAI infection rates. In contrast, others have stated the opinion that cleaning has only a transitory effect on the levels of 
pathogens in the environment and that their numbers rise rapidly following cleaning (Pratt et al., 2007).

A view began to take hold, that by employing an objective assessment of the efficacy of cleaning this would axiomatically provide some sort of measurable indication of the extent to which the causative organisms of HAls were being eliminated from the environment. The very act of comparing practices in the food processing industry with those of the healthcare sector caused attention to fix on the use in that particular sector of monitoring ATP on surfaces. Whilst it was accepted that the introduction of ATP testing would aid in identifying instances of organic soiling, there was also an assumption that the contribution to the overall ATP count by micro-organisms responsible for HAls could be identified against background ATP levels. Coupled to this was the notion that ATP measurements could then be in effect correlated with the traditional method of estimating the presence of such organisms in the environment - i.e. viable plating. This is considered in the next section.

\section{Micro-organisms and ATP}

\section{Correlations of ATP with Microbial Concentration}

It is pertinent to examine what evidence has been reported for the existence of a correlation between microbial counts and ATP levels. The literature does in fact contain a number of studies which present strong evidence for the existence of such a correlation. Table 1 contains a number of examples from widely different studies where relatively high correlations between microbial numbers and ATP levels have been obtained. The former are expressed as colony forming units (CFU) and the latter in relative light units (RLU) - this being the units displayed by commercial luminometers. The entries in the table are restricted to studies which actually quote 
coefficients of determination (i.e. $\mathrm{R}^{2}$ values). For example, the work of Ivancic et al. (2008) on the detection of microbial pathogens in urine contains a figure in which RLUs are plotted against CFUs and which by eye seems to be a good correlation, however because an $\mathrm{R}^{2}$ value was not given the study was not included in the table. In the majority of cases the measurements cited in the table have been corrected for the contribution of ATP from somatic cells and other organic matter apart from the organisms that the assay is attempting to target. However, it should be noted that few commercially available rapid ATP test kits offer this facility. The examples shown in the table cover a very diverse range of applications, and there is in general very little in common between the entries other than the fact that the measurements were conducted in environments that may be described as being fairly defined and that this evidently had consequences for the diversity of the microflora associated with those environments.

Unsurprisingly, high values of coefficients of determination were obtained for cells of E. coli grown specifically for immobilisation in hydrogel beads (Wadhawan et al., 2010). More unexpected are the high values obtained for the natural microflora of melon (Ukuku et al., 2005). Certain interventions can apparently have a powerful effect in achieving high values of $\mathrm{R}^{2}$. For example, Tifft and Spiegel (1976) initially obtained a coefficient of determination of only 0.035 for the relationship between CFU and RLU for a municipal wastewater. However, the value rose to 0.759 following the disinfection of the wastewater with chlorine-based compounds. The latter appeared to have eliminated much of the microbial diversity of the wastewater leaving primarily faecal coliforms that were relatively resistant to chlorine. This might also explain the relatively high $\mathrm{R}^{2}$ value shown in the table for cows' udders. The main contaminants that could be expected to be present on this particular organ 
would be faeces and soil - both containing a rich and diverse microflora. However, washing followed by disinfection with iodoform must evidently have resulted in a significant reduction in this diversity leaving a microbial population that could accurately be detected using an appropriate agar medium resulting in the relatively high $\mathrm{R}^{2}$ value of 0.64 . In most instances the data presented in the table was obtained without disinfective treatments or indeed, any other interventions. This would suggest that in such cases the natural microflora of the particular environments referred to in the table might have naturally been subject to various influences that limited its diversity in some way thus enabling high correlation coefficients to be obtained.

By contrast Figure 1 shows a plot of CFU versus RLU values obtained for various surfaces within a typical hospital ward including table tops, floors, armchair rests etc. The $\mathrm{R}^{2}$ value is very low at 0.078 . This poor correlation is typical of that previously reported for such environments (Willis et al., 2007).

\section{Intracellular ATP Content}

An fundamental consideration is that of the ATP content of individual microbial cells. Firstly, are there differences in specific ATP content between microbial representatives from different taxa of organisms? In addition, can it be assumed that an organism's ATP pool is fixed and not affected by either its physiological conditions or its environment? Table 2 shows estimates of the intra-cellular pools of ATP expressed as moles of ATP per cell for bacteria, bacterial spores, yeast and fungal spores. Most of the data shown in the table are direct citations from the respective studies, however in a small number of cases where the authors had not specifically expressed cellular ATP values in the form shown in the table, these were 
simply re-calculated from published data. The range for bacteria spans some four orders of magnitude, with bacteria isolated from natural environments generally containing less ATP per cell than those that were cultured in the laboratory. The data of Li et al. (2003) for laboratory-grown Listeria monocytogenes appears as an exception to this at $3.44 \times 10^{-21}$ moles ATP per cell. The values obtained by Venkateswaran et al. (2003) ranging from $0.28 \times 10^{-15}$ to $2.5 \times 10^{-15}$ moles per cell seem surprisingly high for organisms isolated from the environment, albeit an artificial one. However, these workers were able to detect a difference in ATP content between micro-organisms isolated from clean rooms and what they termed 'ordinary rooms' at a space technology centre. The values for yeast and fungal spores are in general higher than those for bacteria but the data of Autio and MattilaSandholm (1992) for Saccharomyces cerevisiae seem anomalously low. More recently Hattori et al. (2003) measured the ATP content of 54 species of laboratorycultivated micro-organisms. The values ranged from 0.4 to $16.7 \times 10^{-18}$ moles ATP per CFU.

Holm-Hansen (1970) showed that the ATP content of a large diversity of algal species correlated very well to their carbon content. Surprisingly, algal ATP content spanned six orders of magnitude and ranged from less than $1.0 \times 10^{-15}$ to $4.2 \times 10^{-10}$ moles presumably reflecting the large size range of the 50 or so species of algae examined. Later, Holm-Hansen (1973) was able to add data on the ATP content of bacteria, yeast and spores to his original plot and maintain the high correlation with cell carbon content. The ATP content of microbial isolates obtained from a variety of locations within a space technology centre by Venkateswaran et al. (2003) could also be grouped according to cell size, with that of yeast generally yielding higher levels of ATP per cell than those of bacteria. However, the divisions were not clear 
cut and there was a certain amount of overlap between the groupings. Concentrating on the bacterial flora of natural waters, (Hammes et al., 2010) obtained a reasonably good correlation of ATP content when plotted against cell volume as obtained using flow cytometry.

\section{ATP Content of Spores}

Bacterial endospores, or 'spores' as they are generally referred to, merit special consideration. Produced by certain bacteria in response to environmental stress, these so-called 'resting bodies' are able to survive extreme environmental conditions better than their vegetative counterparts. They are particularly relevant to healthcare settings. For example, Kim et al. (1981) found that spores of $C$. difficile were able to maintain viability on hospital floors for up to 5 months.

Although only a single source was found specifically quoting the ATP content of bacterial spores (Venkateswaran et al., 2003), the value is at the lower range of those for bacteria. The ATP content of spores of Paecilomyces farinosus as determined by Lane et al. (1988) appears relatively high, and this might be a reflection of the large size of the spores of this particular fungus. The bacteria isolated from salt marshes by Wilson et al. (1981) yielded ATP levels comparable to bacterial spores as did - rather surprisingly - laboratory-grown Listeria monocytogenes (Li et al., 2003). Notwithstanding, corroboration that the ATP content of bacterial spores is considerably lower than that of their respective vegetative cells is provided by earlier work of Setlow and Kornberg (1970) who compared ATP levels in vegetative cells and spores of Bacillus megaterium. These workers found the ATP level (quoted as nmoles per $g$ dry cells or spores) was some 250 fold higher in vegetative cells than in spores. They also showed that whilst ATP 
levels in spores were low, the levels of adenosine diphosphate (ADP) and adenosine monophosphate (AMP) in spores was very much higher than in vegetative cells, and that once germination was initiated these nucleotides were rapidly converted to ATP. Fajardo-Cavazos et al. (2008) were able to detect the presence of as few as $30 \mathrm{~B}$. subtilis and $19 B$. pumilus viable vegetative bacteria but required considerably greater numbers of the spores of these bacteria (respectively $2 \times 10^{7}$ and $1.28 \times 10^{7}$ ) to obtain ATP readings at the lower limit of detection of their luminometer. These differences in ATP content between vegetative cells and spores are very much greater than those cited by Setlow and Kornberg (1970) and the discrepancy might be a reflection of the difficulties in liberating ATP from spores using commercial test reagents.

\section{Factors Affecting Intracellular ATP Content}

The second consideration that must be addressed is whether the ATP content of a microbial cell can be treated as a fixed entity. Fairbanks et al. (1984) examined the effects of moisture stress and nutrient status on the growth of Pseudomonas paucimobilis in soil. Having grown the cells under what they termed 'moisture stress', they found that cell ATP content could be increased 2.2 fold by rewetting dry soils and that furthermore, the addition of glucose and ammonium salts increased ATP levels 5.9 and 2.8 fold respectively. Schneider and Gourse (2004) found that ATP levels in laboratory-grown E. coli remained constant with growth rate, and claimed that earlier work that had presented evidence of growth rate-related differences were in fact at fault due to the method used to extract ATP from the cells.

Micro-organisms respond to environmental stresses by activating survival strategies. Sporulation, mentioned above, is one such response and primarily occurs in species 
belonging to the genera Bacillus and Clostridium. Certain non-sporulating bacteria appear to survive hostile environments by entering a state that may be broadly described as dormancy or 'suspended animation'. For example, a recent study reported that MRSA had the ability to survive on dry plastic surfaces for over 1000 days (Chaibenjawong and Foster, 2011). In such states metabolic activity must be maintained at a very low rate. Gengenbacher et al. (2010) reported that in response to nutrient starvation Mycobacterium tuberculosis was able to downregulate its ATP levels to one fifth that of normal. As a consequence of this the bacterium entered a non-replicating state, and this enabled it to resist the effects of anti-tuberculosis drugs. Li et al. (2003) observed that when stressed cells of Listeria monocytogenes were activated by the addition of sucrose, ATP levels rose $250 \%$, whereas that of unstressed controls only rose by $50 \%$.

A state related to starvation but which is distinct from it (Heim et al., 2002) has been termed the 'viable but not culturable' state or VBNC. As the name implies, bacteria in this state maintain viability but lose the ability to grow on artificial laboratory media. Much that is known of the VBNC state relates to work conducted on the genus Vibrio (Oliver et al., 1995). Relatively few studies have been conducted on the bacteria implicated in HAI. One exception is the work done on a vancomycin resistant enterococcus (VRE) by Lleo et al. (2003) who showed that Enterococcus faecalis and $E$. faecium maintained their resistance to vancomycin on being resuscitated from the VBNC state. A number of factors have been shown capable of inducing the VBNC state in bacteria including incubation outside the normal temperature range of growth and even exposure to white light (Oliver, 2010). According to this author, although cells undergo a reduction in size and decreases in macromolecular synthesis and respiration rates, ATP levels remain high in the VBNC state. However, 
Federighi et al. (1998) had earlier shown that Campylobacter jejuni reduced its ATP levels to $1 / 50^{\text {th }}$ during the first 12 days of starvation after which they remained constant.

Hospital environments will contain a wide variety of micro-organisms that range from the fully and lustily viable to the certifiably dead. Terms such as 'VBNC', starved' and 'sub-lethally injured' may be seen as attempts to characterise cells in between these two extremes. However, the distinction between these terms may not always be clear cut and there will inevitably be some degree of overlap between them. There is one aspect of this in which consensus appears to prevail, and this is that only about $1 \%$ of the micro-organisms in the environment are culturable using artificial growth media (Amann et al., 1995; Vartoukian et al. 2010).

Any growth medium that is used to assess the numbers of micro-organisms present in a particular environment will inevitably be selective. The solid growth media used to obtain 'total viable counts' (TVC) are typically formulated for the detection of bacteria rather than yeast and other fungi. Rapid ATP kits will also display a bias in that micro-organisms from different taxa will differ in the ease with which the ATP contained within them can be released (Lappalainen et al., 2000) but this would be very unlikely to correlate with culturability on any particular medium. Non-microbial sources of ATP such as foodstuffs and bodily fluids will also be detected.

Desquamated human skin cells will also be present in most environments. Beggs et al. (2008) estimated that an adult sheds some $10^{8}$ cells in a 24 hour period and that furthermore each desquamated cell is associated with about 100 bacteria. We (Malik and Shama, unpublished) have found that desquamated skin cells will also contribute an ATP signal and that even after inactivating the bacteria associated with such cells by irradiating them with UV-C, an ATP signal was still detectable. 
There is still much that remains unknown about the fate of ATP in cells that are losing their ability to reproduce and metabolize. Oliver (2010) claimed that ATP is rapidly lost from dead cells but did not offer supporting evidence for his claim. HolmHansen (1973) measured ATP concentrations in marine phytoplankton that had either been heated to $60^{\circ} \mathrm{C}$ for a 'few minutes' or else stored at $-20^{\circ} \mathrm{C}$ for a 'few hours' and was not able to detect ATP after such treatments. However, he provided no information as to the rates over which the disappearance occurred, and it should not necessarily be assumed that these findings are in any way general.

More recently Cowan \& Casanueva (2007) found that exogenous ATP to have a relatively short half-life under Antarctic dry valley summer conditions varying between 0.5 and 30 hours. They also found that measurements of ATP titre in Antarctic soils were attributable to the presence of 'endogenous ATP' i.e. produced biogenically, and therefore indicative of the presence of viable bacteria. A contrasting conclusion regarding the fate of ATP in an extreme environment albeit of a very different sort was arrived at by Schuerger et al. (2008). This study was concerned with identifying molecules that might be considered as 'signatures' to the presence of life on other planets - notably Mars. Schuerger et al. (2008) conducted kinetic measurements and then constructed a model that predicted that pure ATP might survive for 'up to decades' under Martian conditions that are predominantly characterized by high UV fluxes. Fajardo-Cavazos et al. (2008) extended this work to investigating the fate of endogenous ATP produced by living cells following exposure to simulated Martian conditions. Elements of their work have direct terrestrial significance. These same workers also showed that when vegetative bacterial cells and spores were allowed to desiccate in the open air, widely varying reductions in 
viability (as determined by plating) were obtained, but the ATP associated with these organisms remained relatively stable. Vegetative cells of Bacillus subtilis suffered a 5 log decrease in viability yet the ATP content of the cells declined by only approximately 1 log. They also confirmed the earlier findings of Setlow and Kornberg (1970) regarding spore ATP levels mentioned above. However, Fajardo-Cavazos et al. (2008) claimed that the enzymes necessary to convert AMP and ADP to ATP were 'pre-packaged' as they put it (i.e. constitutive) in spores, and that even if spores were non-viable, conditions during ATP testing might conceivably allow the relevant enzymes to become activated leading to an ATP 'surge' which would lead to a false positive signal that could confound the true readings. This is an intriguing point and one which merits further investigation.

\section{The Call for Hygiene Standards in Healthcare Establishments}

\section{Formulation of Standards}

We have attempted to show that, in the UK at least, it is possible to draw a connection between the crisis presented by mounting cases of HAls and suggestions that ATP testing of surfaces might offer a solution to the problem (Griffith et al. 2000). Similarly, it was from the UK that calls for the implementation of hygiene standards for the healthcare sector along the lines of those used in the food industry first came to be made (Griffith et al., 2000; Malik et al., 2003). Whether the standard should be set at 2.5 CFU or $5 \mathrm{CFU}$ per $\mathrm{cm}^{2}$ in the healthcare environment remains the subject of an on-going debate (Mulvey et al., 2011). Apart from the delay inherent in obtaining plate count results, such tests require specially trained staff to conduct them. A number of workers have suggested that standards should be formulated directly in terms of RLUs because of the ease with which such measurements can be obtained using ATP test kits (Lewis et al., 2008; Mulvey et al., 2011). There is 
nothing fundamentally unsound with this approach; difficulties only arise if attempts are made to 'translate' standards set in terms of CFUs directly to RLUs for the reasons that we have previously discussed. In addition, insufficient attention has been paid to the effects arising from the poor repeatability and reproducibility inherent in the process of sampling at a surface using swabs. A further difficulty is that at low RLU readings the difference in sensitivity between luminometers may become apparent (Carrick et al., 2001).

The standards currently in place in the food industry may have been said to have evolved over time based on the practices and nature of the environment prevalent in that particular sector. Therefore it is relevant to consider these factors here and to compare and contrast them with those found in healthcare establishments.

\section{Sampling from Surfaces}

Surface counts can be made either by swabbing the surface and then transferring the sample onto a suitable agar, or by using a dip slide or RODAC plate in which case the surface microflora are transferred directly onto agar. Perhaps not surprisingly each method will have its characteristic 'pickup efficiency' and these will vary according to a number of factors including the characteristics of the organisms present at the surface, the nature of the surface itself and the degree of wetness of the agar (Lemmen et al., 2001; Pinto et al., 2009).

In virtually all cases rapid ATP kits make use of swabs to sample the surface. Most of the relevant work that has been done on the swabbing process itself has involved depositing pure microbial cultures onto surfaces and estimating the numbers that are recovered following swabbing. However, when swabbing is conducted to measure surface ATP, each class of ATP-contributing material will be recovered from a 
particular surface with an efficiency that will be dependent on that material's characteristics. Whilst this would normally include micro-organisms, caution must be urged in directly translating findings conducted purely with microbial cultures to studies concerned with ATP measurements.

Whilst relatively straightforward to carry out, the processes involved in swabbing surfaces are actually quite complex if examined in detail. The swab is first removed from its container and dragged over the surface in a zig-zag fashion. The geometry of certain swab tips enables them to be rotated during surface sampling and this helps to ensure that the entire tip bears material from the surface and ultimately facilitates subsequent release. However, some configurations of swab tips prohibit this action (Moore and Griffith, 2007). Unsurprisingly as these authors demonstrated, the greater the mechanical force expended during sampling the greater was the pickup efficiency from wet surfaces. Lower recoveries were obtained from dry surfaces, and Moore and Griffith (2007) speculated that in addition to differences in the pickup efficiencies between wet and dry surfaces, their findings might also reflect damage to micro-organisms by the pressure of the swab itself. Whether the forces necessary to physically disrupt bacteria can be generated during swabbing is uncertain. However, as far as ATP measurements are concerned this would be less problematic as, if cell rupture did occur, the ATP released would presumably be detected from the lysed cells. The degree to which particulate matter will adhere to a surface will depend on the hydrophobicity of the surface, with greater hydrophobicity resulting in greater adhesion (Bower et al., 1996). Some quite marked differences in efficiencies of removal have been recorded even between spores of different species of the same genus (Probst et al., 2011) which must partly reflect differences in spore hydrophilicity. In addition, the manner in which organisms are deposited at the 
surface will also influence the efficiency with which they can be removed as Probst et al. (2011) showed when comparing aerosolised and drop-deposited spores. Pickup efficiency is also affected by the concentration of organisms actually present at the surface, with the efficiency actually decreasing with increasing bacterial concentration (Montville and Schaffner, 2003).

The physical nature of the surface will also be an important determinant of the pickup efficiency. Food processing environments are characterised by a preponderance of smooth surfaces in accordance with the precepts of hygienic design (Anon., 1993). Wherever practical certain grades of stainless steel (304 and 316) are used in the manufacture of food processing equipment and worktops in food preparation areas. These steels can be obtained in a variety of surface finishes and smooth finishes are particularly favoured because this reduces the likelihood of particles of food and other matter being retained at the surface which facilitates cleaning (Woodling and Moraru, 2005; Whitehead \& Verran, 2006). Most significantly there is a marked absence of textiles, which by contrast, are common in the healthcare environment. Textiles can be both porous and have rough surfaces which militate against the release of micro-organisms from their surfaces. In fact Probst et al. (2011) had to devise a special procedure - which they termed 'wipe-rinse' to achieve appreciable recovery of spores from a particular textile material that had a rough finish this was because traditional swabbing yielded very low spore recoveries. In certain cases micro-organisms may be present on a surface in the form of a biofilm. Biofilms are ordered structures in which micro-organisms are distributed in a polysaccharide matrix. This will affect the ease with which such micro-organisms may be physically removed from the surface (Bower et al., 1996). Following surface sampling the recovered material must then be released from the swab in order that the required 
analysis may be carried out. This is influenced both by the mechanical procedure employed to achieve this (Rose et al., 2004) and the material of the swab itself (Moore and Griffith, 2007; Edmonds, 2009). In recent years both new materials and new devices have been introduced into the so-called 'near patient environment' in hospital wards which have had unintended consequences for cleanability. To take one example, ergonomically adjustable beds are of more complex construction than the non-adjustable type, and typically incorporate more polymeric components. Both of these factors militate against ease of cleaning. The increased mechanical complexity provides additional niches where dust etc. may accumulate, and polymers are more easily abraded than metals, and dirt and dust may become trapped at scratched surfaces.

In the course of conducting ATP assays as part of a multi-hospital trial we observed that the degree of wetness of the swabs from a particular manufacturer was highly variable both within batches and between batches and that this had a marked effect on pickup efficiency. A number of previous studies have shown that moistened swabs are more efficient at picking up material from surfaces than are dry swabs (Griffith, 1996; Davidson et al., 1999; Landers et al., 2010).

The imposition of a single universal standard throughout the healthcare sector could prove problematic because the infrastructure of healthcare environments is very diverse. The nature and standard of equipment in an intensive care ward will be quite different from that of an emergency assessment unit. Care standards in these settings cannot not be identical and similarly, any ATP/hygiene standards would need to reflect the different physical infrastructure and the attendant risks arising from contamination of the environment. Setting of locally achievable cleaning 
standards using best cleaning practices combined with trend analysis is likely to be a better way forward.

\section{Inherent Limitations in Luminescence-based ATP Assays}

Any measurement system used for assessing quality control of a particular process needs to be inherently robust with regards to sensitivity, repeatability and reproducibility. Additionally measurements should not be adversely affected by substances such as commonly used cleaning agents and sanitisers that are likely to be present at surfaces.

The very act of cleaning and disinfection of surfaces in the environment will inevitably result in those surfaces becoming contaminated with traces of the agents used for cleaning. Such surface residues will inevitably be picked up by the swabs used to sample surfaces for the presence of ATP, and will subsequently be released into the reagent tubes which form part of all rapid ATP test kits. There is evidence to show that these agents can have a confounding effect on ATP measurements as conducted using luciferin-luciferase based systems. For example, Velazquez \& Feirtag (1997) tested the effects of a number of cleaning agents and sanitizers on ATP measurements and defined a 'quencher' as a compound that reduces the light signal generated during the enzymatic reaction, whilst an 'enhancer' was a compound that increases or amplifies the light signal. Many of the agents tested behaved as enhancers at low concentrations but then underwent a transition to become quenchers as their concentrations were increased. In particular, it was found that an acidic foam cleanser at a concentration low enough to enhance the light 
signal was too dilute to inactivate $E$. coli $\mathrm{O} 157: \mathrm{H} 7$. If this combination of circumstances occurred in a food processing plant the result would be interpreted as meaning that the surface in question was not sufficiently clean and that it would require further attention - a false positive outcome which although having required an unnecessary intervention, would not compromise safety. Alkaline foam cleansers on the other hand were found to require much higher concentrations than acidic cleansers for inactivating $E$. coli. Therefore, if traces of an alkaline foam cleanser remained on a particular surface, these might be of a concentration sufficient to quench the light signal but insufficient to ensure adequate disinfection. This would be interpreted as a false negative result with potentially serious consequences for food safety. A similar situation could quite conceivably arise with the organisms responsible for HAls.

Lappalainen et al. (2000) confirmed that disinfectants were able to confound ATP measurements made using the luciferin-luciferase assay, but advocated combining rapid ATP measurements with a bacterial-based test for determining whether disinfectants were present on a surface. Lappalainen et al. (2000) also observed that some of the cleaning agents they tested were chemically similar to those incorporated in commercial ATP test kits for releasing intercellular ATP from microorganisms. They suggested that traces of cleaning agents left on surfaces would be picked up during sampling in e.g. hospitals and that this could enhance the release of ATP from micro-organisms that might also be present in the sample.

The efficacy of different ATP-releasing agents used in the studies referred to in Table 2 may have been a factor in accounting for some of the differences in reported ATP content per cell. That the efficacy of these agents is a factor meriting further work was revealed by Turner et al. (2010) who, using a commercial ATP assay test 
kit and luminometer, reported that the limit of detection of Gram positive bacteria was $10^{2}$ cells whereas that for Gram negative bacteria was $10^{4}$. These workers found that sonicating the Gram negative bacteria helped to release ATP and decreased the detection limit to $10^{3}$ cells.

The potential that certain disinfectants have to interfere in ATP measurements have been acknowledged as potentially posing difficulties within healthcare environments (Mulvey et al., 2011) and at the present time there does not appear to be a solution to this.

Another agent capable of interfering with bioluminescent-based ATP measurements is citric acid (Mubiru et al., 2008). Whilst the work of these authors was intended primarily as a caution against the use of citrate buffers, citric acid is found in a number of foodstuffs - predominantly drinks - and surface contamination by such liquids could therefore also confound ATP measurements.

\section{A Role for ATP Testing in Healthcare?}

Contrasts between Food Processing and Healthcare

In attempting objectively to establish whether there are indeed lessons that the healthcare sector might profitably take from the food industry, it may be worthwhile to acknowledge some of the fundamental differences that exist between them. Perhaps the first place to start is with a brief comparison of the policies for admission to each.

Any person seeking entry to a well-regulated food processing facility must typically complete a questionnaire that includes questions about their own state of health and their most recent movements (e.g. travel overseas etc.). The visitor must then don overalls, hair nets and overshoes and then wash their hands before finally gaining 
entry. This most emphatically is not required as a matter of routine of, say, a visitor to a hospital ward. Of course, there are situations where the level of control could be considered comparable, or even superior to, the hygiene measures adopted by the food industry. A particular example of this is the protective measures put in place for those attending and visiting highly immunologically-impaired patients (Hayes-Lattin et al., 2005). However, the typical hospital ward must be considered 'open' in the sense that there is a more or less free transfer of persons and materials across its boundaries. Those that are ill represent the raison d'être of such establishments, and they will have their own microflora albeit amended by disease. Even though attempts are being introduced to screen patients for carriage of pathogens such as MRSA before admission for elective procedures (Eveillard et al., 2005), there will of course be categories of patients - such as accident and emergency cases - who will be admitted without any form of screening at all. Recent work shows that even the relatively short times in which injured or sick individuals who happen to be carriers of MRSA are transported in ambulances is sufficient to contaminate objects - notably stretchers - in those vehicles, and that this risks transmitting MRSA infection to those subsequently transported in the same ambulances (Eibicht and Vogel, 2011).

Closely associated with patients will be healthcare workers who will naturally also have their own microflora (Loh et al., 2000) that will presumably be distinct from those of their patients. Healthworkers can of course cross-infect patients through hand contact (Peacock et al., 1980) but they can themselves be the unwitting source of disease. Such individuals have been referred to as 'dispersers' or 'cloud healthworkers' because they can shed micro-organisms into the patient environment (Sheretz et al., 2001). Amongst others crossing the boundaries of the healthcare environment are those visiting friends and relatives in hospital. The microbiological 
burden that visitors carry with them is potentially very diverse indeed (Tekerekoğlu et al., 2011) and may be influenced by their occupation and activities.

The deep clean policies hurriedly introduced in the UK National Health Service in the wake of the HAl crisis may be viewed as a further example of attempts to transfer practices from the food processing industry. Although this type of intervention has not been totally abandoned, it has now assumed a less urgent role. The process of deep cleaning naturally requires the removal of patients from hospital wards before being initiated. Steam cleaning is used for walls and inaccessible places but cannot be applied to fixed electronic equipment such as monitors and consoles. Different approaches have been proposed for dealing with such equipment including the use of hydrogen peroxide which can be applied as a vapour (Chan et al., 2011). Even if it were possible to totally eradicate the microbial flora from the typical healthcare environment without stripping it down to its very fabric, it is clear that re-colonisation rates are rapid (Hardy et al., 2007). Re-colonisation starts when the patients (who have not been deep cleaned) are returned to their original hospital ward. Indeed, the upheavals caused by this must rapidly increase the rate at which micro-organisms and other ATP-containing matter are deposited in the environment.

In contrast, modern food processing facilities are designed so that they can regularly be deep-cleaned. The frequency with which this will be done will vary according to the nature of the processing operation being carried out, but in some cases this may even be conducted on a daily basis using whole facility disinfectants which can be released in the form of fine mists or fogs (Burfoot, 1999). Moreover, all equipment is left in place and there are no upheavals similar to those in the healthcare sector when patients are transferred back into their wards. In addition, the equipment and even the very fabric of food processing facilities will have been designed for ease of 
cleaning (Anon., 1993). Interestingly, there is evidence that the so-called 'hygienic design' concept is beginning to be applied in healthcare (Department of Health, 2011; Dong and McGinley, 2009).

It is difficult to see how healthcare environments could adopt the strict policies of the food industry for admission of outsiders into hospital wards without fundamentally changing the nature of hospitals and other healthcare establishments. Whether there is the will to introduce such changes remains unknown. Even attempts to introduce relatively small changes to what are considered to be normal practices, such as measures for improving hand hygiene, are met with resistance and poor compliance (Guilhermetti et al., 2010).

\section{Assessment of Cleanliness in Healthcare Environments}

When it was first suggested that ATP testing might usefully be introduced the prevailing climate was one in which deaths from HAls were mounting rapidly and there was enormous pressure on the authorities responsibleto be seen to act in order to reverse this trend. The notion that driving down ATP readings on surfaces in healthcare establishments through improved cleaning and disinfection practices would be correlated with reductions in the occurrence of the agents responsible for HAls in the environment and that this would therefore lead to reduced incidences of disease is clearly questionable.

The question remains: does ATP though have a role to play in the healthcare sector? All surfaces within healthcare environments must first appear clean as judged by the criterion of visual assessment. However, visual assessment cannot be used to judge the microbiological status of any surface. The scheme put forward by Griffiths et al. (2000) and reproduced diagrammatically in Figure 2 represents one strategy for 
incorporating ATP measurements in cleaning regimens. However, its weaknesses must also be recognised; if a surface is deemed 'high risk' and is tested using a bioluminescence-based ATP assay a false negative result might be generated if the cleaning agent used interferes with the ATP assay. Moreover, it is valid to set standards in terms of RLUs, but for the reasons that we discussed at length relating to the effects on the physiology of micro-organisms brought about by environmental and other effects, there are pitfalls in attempting to translate RLU measurements directly to CFUs even in the absence of confounding substances.

There is another factor which must be borne in mind when introducing new systems of assessment into the work environment and this is the so-called 'Hawthorne Effect'. In essence this is when personnel change their behaviour simply because they are aware that their performance is being monitored, and that the change persists only for the duration of the assessment. This phenomenon was extensively reviewed by Parsons (1974). The Hawthorne Effect has been taken into consideration in studies where surface analysis of ATP was being conducted. In a two phase evaluation of cleaning practices within a teaching hospital, Boyce et al. (2009) provided evidence to suggest that the improvements in cleaning were sustained and actually improved over time. These researchers appreciated that further longer term studies would need to be undertaken to validate their initial findings, but their results should be seen as encouraging.

\section{The Continuing Impact of HAls}

Some, for example Chan et al. (2010) have come to view the whole unfolding of events in the UK in relation to HAls as serving the interests of all participants involved - the press, political parties and even - perversely - the medical 
establishment, and that in reality what was being expressed were deeper anxieties about the apparent randomness of HAls in an era of 'high tech' medicine. Earlier in this review we made mention of how the press in the UK attempted to present the rising incidence of HAls as peculiarly British. But in reality the problem was universal and was, albeit with hindsight, to some extent predictable given the very nature of healthcare establishments and the lax antibiotic prescribing policies that had developed over time. In actual fact with respect to MRSA rates the UK was by no means the worst country affected. The USA, Greece and Portugal (amongst others) all had higher rates, and those for the UK were only marginally higher than those of Israel and Ireland (CDDEP, 2011).

The reality is that HAls continue to pose a significant risk to health and that this carries a number of implications not least being financial ones. The pan-European costs attributable to infections by MRSA alone have recently been estimated as amounting annually to some $€ 380$ million (Köck et al., 2010). There is clearly an incentive to reduce both the human suffering and the costs associated with HAls. What is becoming clear is that no single intervention will ever be likely to solve the problem. Bioluminescence-based ATP testing has a clearly defined contribution to make in initiatives to improve hospital cleaning practices and ensure compliance with cleaning regimes. Its use in this way would constitute a considerable advance over the current dependence on visual assessment for determining cleanliness of the environment and which has been shown to be highly subjective. However, caution needs to be exercised in interpreting ATP readings. Commercially available rapid ATP monitoring systems suffer from a number of limitations: (i) low sensitivity for the detection of microorganisms; (ii) poor repeatability due to the large number of factors influencing pick-up efficiency from surfaces; (iii) interference from certain 
disinfectants and other substances likely to be present in the environment. Readings should therefore never be interpreted as indicative of the presence or otherwise of the agents responsible for HAls.

\section{Acknowledgements}

The authors would like to acknowledge the Engineering and Physical Sciences

Research Council (EPRSC) support for this work (Grant no. EP/D039614/1) via the Health and Care Infrastructure Research and Innovation Centre (HaCIRIC). 


\section{References}

Addanki, S., Sotos, J.F., Rearick, P.D., 1966. Rapid determination of picomole quantities of ATP with a liquid scintillation counter. Anal. Biochem., 14, 261-\&.

Aiken, Z.A., Wilson, M., Pratten, J., 2011. Evaluation of ATP bioluminescence assays for potential use in a hospital setting. Infect. Control Hosp. Epidemiol., 32, 507-509.

Amann, R.I., Ludwig, W., Schleifer, K.H., 1995. Phylogenetic identification and in situ detection of individual microbial cells without cultivation. Microbiol Rev., 59, 143-169.

Anonymous, 1957. Dirty Hospitals. Time Magazine $1^{\text {st }}$ April. http://www.time.com/time/magazine/article/0,9171,867585,00.html. Accessed $15^{\text {th }}$ August, 2011.

Anonymous, 1993. Hygienic equipment design criteria. Trends Food Sci. Technol., 4, 225-229.

Autio, K., Mattila-Sandholm, T., 1992. Detection of Active Yeast Cells (Saccharomyces cerevisiae) in Frozen Dough Sections. Appl. Env. Microbiol., 58, 2153-2157.

Baumann, H.E., 1974. HACCP concept and microbiological hazard categories. Food Technol., 28, 30-34

Beggs, C.B., Kerr, K.G., Noakes, C.J., Hathway, E.A., Sleigh, P.A., 2008. The ventilation of multiple-bed hospital wards: Review and analysis. Amer. J. Infect. Control, 36, 250-259. 
Bell, C., Stallard, P.A., Brown S.E., Standley, J.T.E., 1994. ATP-bioluminescence techniques for assessing the hygienic condition of milk transport tankers. Int. Dairy J., 4, 629-640.

Bell, C., Bowles, C.D., Toszeghy, M.J.K., Neaves, P., 1996. Development of a hygiene standard for raw milk based on the Lumac ATP-bioluminescence method. Int. Dairy J., 6, 709-713.

Bower, C.K., McGuire, J., Daeschel, M., 1996. The adhesion and detachment of bacteria and spores on food-contact surfaces. Trends Food Sci. Technol., 7, 152157.

Boyce, J.M., 2007. Environmental contamination makes an important contribution to hospital infection. J. Hosp. Infect., 65 Suppl 2, 50-54.

Boyce J.M., Havill, N.L., Dumigan D.G., Golebiewski, M., Balogun, O., Rizvani, R., 2009. Monitoring the effectiveness of hospital cleaning practices by use of an adenosine triphosphate bioluminescence assay. Infect. Control Hosp. Epidemiol., 30, 678-684.

Burfoot, D., 1999. Fogging for the disinfection of food processing factories and equipment. Trends Food Sci.Technol., 10, 205-210.

Carrick, K, Barney, M., Navarro, N., Ryder, D., 2001.The comparison of four bioluminometers and their swab kits for instant hygiene monitoring and detection of microorganisms in the brewery. J. Inst. Brew., 107, 31-37.

Center for Disease Dynamics, Economics and Policy. 2011.

http://www.cddep.org/ResistanceMap/overview/SA. Accessed 13 ${ }^{\text {th }}$ August, 2011. 
Chaibenjawong, P., Foster, S. J., 2011. Desiccation tolerance in Staphylococcus aureus. Arch. Microbiol., 193, 125-135.

Chan, H.T., White, P., Sheorey, H., Cocks, J., Waters, M.J., 2011. Evaluation of the biological efficacy of hydrogen peroxide vapour decontamination in wards of an Australian hospital. J. Hosp. Infect., 79, 125-128.

Chan, P., Dipper, A, Kelsey, P., Harrison, J., 2010. Newspaper reporting of meticillinresistant Staphylococcus aureus and "the dirty hospital". J. Hosp. Infect., 75, 318-22.

Chen, F.C., Godwin, S.L., 2006. Comparison of a rapid ATP bioluminescence assay and standard plate count methods for assessing microbial contamination of consumers' refrigerators. J. Food Prot., 69, 2534-2538.

Collins, B.J. 1988. The hospital environment: how clean should a hospital be? J. Hosp. Infect. 11 (Supplement A) 53-56.

Cowan, D. A, Casanueva, A. 2007. Stability of ATP in Antarctic mineral soils. Polar Biol. 30, 1599-1603.

Crawford, P., Brown, B., Nerlich, B., Koteyko, N., 2008. The "moral careers" of microbes and the rise of the matrons: An analysis of UK national press coverage of methicillin-resistant Staphylococcus aureus (MRSA) 1995-2006. Health Risk Soc., 10, 331-347.

Dancer, S. J., 2008. Importance of the environment in meticillin-resistant Staphylococcus aureus acquisition: the case for hospital cleaning. Lancet Infect. Dis., 8, 101-113. 
Davidson, C.A., Griffith, C.J., Peters, A.C, Fielding, L.M., 1999. Evaluation of two methods for monitoring surface cleanliness - ATP bioluminescence and traditional hygiene swabbing. Luminescence. 14, 33-38.

Department of Health, 2008. From deep clean to keep clean: learning from the deep clean programme.

http://www.dh.gov.uk/en/Publicationsandstatistics/Publications/PublicationsPolicyAn dGuidance/DH 089716. Accessed $1^{\text {st }}$ October, 2011.

Department of Health, 2011. Design Bugs Out - Product Evaluation, November 2011, HCAI Technology Innovation Programme.

http://www.dh.gov.uk/prod consum dh/groups/dh digitalassets/documents/digitalas set/dh 131199.pdf. Accessed $2^{\text {nd }}$ November, 2011.

Dong, H., McGinley, C., 2009. Design bugs out: a design study of hospital bedside chairs and commodes. Bura.brunel.ac.uk/bitstream/2438/4563/3. Accessed $15^{\text {th }}$ September, 2011.

Eibicht, S. J., Vogel, U., 2011. Meticillin-resistant Staphylococcus aureus (MRSA) contamination of ambulance cars after short term transport of MRSA-colonised patients is restricted to the stretcher. J. Hosp. Infect., 78, 221-225.

Edmonds, J. M., 2009. Efficient methods for large-area surface sampling of sites contaminated with pathogenic microorganisms and other hazardous agents: current state, needs, and perspectives. Appl. Microbiol. Biotechnol., 84, 811-6. 
Ellerbroek, L., Lox, C., 2004. Investigation on the use of neck skin for microbial process control of fresh poultry meat with the ATP Bioluminescence method. Deutsch. Tierarzt. Wochensch, 111, 181-184.

Eveillard, M., Lancien, E., Barnaud, G., Hidri, N., Gaba, S., Benlolo, J.A., JolyGuillou, M., 2005. Impact of screening for MRSA carriers at hospital admission on risk-adjusted indicators according to the imported MRSA colonization pressure. J. Hosp. Infect., 59, 254-8.

Fairbanks, B. C., Woods, L. E., Bryant, R. J., Elliott, E. T., Cole, C. V., Coleman, D. C., 1984. Limitations of ATP estimates of microbial biomass. Soil Biol. Biochem., 16, 549-558.

Fajardo-Cavazos, P., Schuerger, A.C., Nicholson, W.L., 2008. Persistence of biomarker ATP and ATP-generating capability in bacterial cells and spores contaminating spacecraft materials under earth conditions and in a simulated martian environment. Appl. Env. Microbiol., 74, 5159-5167.

Federighi, M., Tholozan, J.L., Cappelier, J.M., Tissier, J.P., Jouve, J.L., 1998. Evidence of non-coccoid viable but non-culturable Campylobacter jejuni cells in microcosm water by direct viable count, CTC-DAPI double staining, and scanning electron microscopy. Food Microbiol., 15, 539-550.

Finger, R., Sischo, W.M., 2001. Bioluminescence as a technique to evaluate udder preparation. J. Dairy Sci., 84, 818-823.

Fraga, H., 2008. Firefly luminescence: a historical perspective and recent developments. Photochem. Photobiol. Sci., 7, 146-158. 
Gengenbacher, M., Rao, S.P.S., Pethe, K., Dick, T., 2010. Nutrient-starved, nonreplicating Mycobacterium tuberculosis requires respiration, ATP synthase and isocitrate lyase for maintenance of ATP homeostasis and viability. Microbiol., 156, 81-87.

Griffith, C. J., Cooper, R. a, Gilmore, J., Davies, C., Lewis, M., 2000. An evaluation of hospital cleaning regimes and standards. J. Hosp. Infect., 45, 19-28.

Griffiths, M.W., 1996. The role of ATP bioluminescence in the food industry: New light on old problems. Food Technology, 50, 62-72.

Guilhermetti, M., Wiirzler, L.A.M., Facio, B.C., Furlan, M.D., Meschial, W.C., Tognim, M. C.B., Garcia, L.B., Cardoso, C.L., 2010. Antimicrobial efficacy of alcohol-based hand gels. J. Hosp. Infect. 74, 219-224.

Guillou, S., Besnard, V., El Mur, N., Federighi, M., 2003. Viability of Saccharomyces cerevisiae cells exposed to low-amperage electrolysis as assessed by staining procedure and ATP content. Int. J. Food Microbiol., 88, 85-89.

Hammes, F., Goldschmidt, F., Vital, M., Wang, Y., Egli, T., 2010. Measurement and interpretation of microbial adenosine tri-phosphate (ATP) in aquatic environments. Water Res., 44, 3915-3923.

Hardy, K. J., Gossain, S., Henderson, N., Drugan, C., Oppenheim, B. A, Gao, F., et al. 2007. Rapid recontamination with MRSA of the environment of an intensive care unit after decontamination with hydrogen peroxide vapour. J. Hosp. Infect., 66, 360368. 
Hayes-Lattin, B., Leis, J.F., Maziarz, R.T., 2005. Isolation in the allogeneic transplant environment: how protective is it? Bone Marr.Transplant., 36, 373-381.

Heim, S., Del, M., Lleo, M., Bonato, B., Guzman, C.A., Canepari, P., 2002. The viable but nonculturable state and starvation are different stress responses of Enterococcus faecalis , as determined by proteome analysis. J. Bact., 184, 67396745.

Holm-Hansen, O., 1970. ATP Levels in Algal Cells as Influenced by Environmental Conditions. Plant Cell Physiol., 11, 689-700.

Holm-Hansen, O., 1973. Determination of total microbial biomass by measurement of adenosine triphosphate. In Stevenson, H., Colwell, R.R. Estuarine Microbial Ecology, University of South Carolina Press, Columbia, SC.

Ivancic, V., Mastali, M., Percy, N., Gornbein, J., Babbitt, J.T., Li, Y., Landaw, E.M., Bruckner, D.A., Churchill, B.M., Haake, D.A., 2008. Rapid antimicrobial susceptibility determination of uropathogens in clinical urine specimens by use of ATP bioluminescence. J. Clin. Microbiol., 46, 1213-1219.

Jarvis, W.R. 2007. The United States approach to strategies in the battle against healthcare-associated infections, 2006: transitioning from benchmarking to zero tolerance and clinician accountability. J. Hosp. Infect., 65, 3-9.

Kim, K.H., Fekety, R., Batts, D.H., Brown, D., Cudmore, M., Silva, J., Waters D., 1981. Isolation of Clostridium difficile from the environment and contacts of patients with antibiotic-associated colitis. J. Infect. Dis., 143, 42-50. 
Koeck, R., Becker, K., Cookson, B., van Gemert-Pijnen, J.E., Harbarth, S., Kluytmans, J., Mielke, M., Peters, G., Skov, R.L., Struelens, M.J., Tacconelli, E., Torne, A.N., Witte, W., Freidrich, A.W., 2010. Methicillin-resistant Staphylococcus aureus (MRSA): burden of disease and control challenges in Europe.

Eurosurveillance, 15, 12-20.

Kramer, A., Schwebke, I., Kampf, G., 2006. How long do nosocomial pathogens persist on inanimate surfaces? A systematic review. BMC Infect. Dis. 6, Article No. 160.

Lacey, R.W., 1987. Multiresistant Staphylococcus aureus - A suitable case for inactivity. J. Hosp. Infect., 9, 103-105.

Lagace, L., Girouard, C., Dumont, J., Fortin, J., Roy, D., 2002. Rapid prediction of maple syrup grade and sensory quality by estimation of microbial quality of maple sap using ATP bioluminescence. J. Food Sci., 67, 1851-1854.

Landers, T.F., Hoet, A., Wittum, T.E., 2010. Swab type, moistening, and preenrichment for Staphylococcus aureus on environmental surfaces. J. Clin. Microbiol., 48, 2235-2236.

Lane, B.S., Humphreys, A.M., Thompson, K., Trinci, A.P.J., 1988. ATP content of stored spores of Paecilomyces farinosus and the use of ATP as a criterion of spore viability. Trans. Brit. Mycol. Soc., 90, 109-111.

Lappalainen, J., Loikkanen, S., Havana, M., Karp, M., Sjoberg, A.M., Wirtanen, G., 2000. Microbial testing methods for detection of residual cleaning agents and 
disinfectants - Prevention of ATP bioluminescence measurement errors in the food industry. J. Food Prot., 63, 210-215.

Lemmen, S. W., Häfner, H., Zolldann, D., Amedick, G., Lütticken, R., 2001.

Comparison of two sampling methods for the detection of gram-positive and gramnegative bacteria in the environment: moistened swabs versus Rodac plates. Int. J. Hyg. Environ. Health, 203, 245-8.

Lewis, T., Griffith, C., Gallo, M., Weinbren, M., 2008. A modified ATP benchmark for evaluating the cleaning of some hospital environmental surfaces. J. Hosp. Infect., 69, 156-163.

Li, J., Kolling, G. L., Matthews, K. R., Chikindas, M. L., 2003. Cold and carbon dioxide used as multi-hurdle preservation do not induce appearance of viable but non-culturable Listeria monocytogenes. J. Appl. Microbiol., 94, 48-53.

Lleo, M., Bonato, B., Signoretto, C., Canepari, P., 2003. Vancomycin resistance is maintained in Enterococci in the viable but nonculturable state and after division is resumed. Antimicrob. Agents Chemother., 47, 1154-1156.

Loh, W., Ng, V. V., Holton, J., 2000. Bacterial flora on the white coats of medical students. J. Hosp. Infect., 45, 65-68.

Lundin, A., 2000. Use of firefly luciferase in ATP-related assays of biomass, enzymes, and metabolites. Meth. Enzymol., 305, 346-371.

Luo, J., Liu, X., Tian, Q., Yue, W., Zeng, J., Chen, G., Cai, X., 2009. Disposable bioluminescence-based biosensor for detection of bacterial count on food. Anal. Biochem. 394, 1-6. 
Malik, R.E., Cooper, R.A., Griffith, C.J., 2003. Use of audit tools to evaluate the efficacy of cleaning systems in hospitals. Amer. J. Infect. Control, 31, 181-187. Montville, R., Schaffner, D.W., 2003. Inoculum size influences bacterial cross contamination between surfaces. Appl. Env. Microbiol., 69(12), 7188-7193.

Moore, G., Griffith, C., 2007. Problems associated with traditional hygiene swabbing: the need for in-house standardization. J. Appl. Microbiol., 103, 1090-103.

Mubiru, D.N., Coyne, M.S., Grove, J.H., 2008. Citric acid interferes with adenosine triphosphate determination by bioluminescence. Anal. Lett., 41, 2587-2594.

Mulvey, D., Redding, P., Robertson, C., Woodall, C., Kingsmore, P., Bedwell, D., Dancer, S.J., 2011. Finding a benchmark for monitoring hospital cleanliness. J. Hosp. Infect., 77, 25-30.

Ng, L.K., Taylor, D.E., Stiles, M.E., 1985. Estimation of Campylobacter spp. in broth culture by bioluminescence assay of ATP. Appl. Env. Microbiol., 49, 730-731.

Office for National Statistics. 2011a. Deaths from MRSA in England and Wales. http://www.statistics.gov.uk/cci/nugget.asp?id=1067 MRSA. Accessed $15^{\text {th }}$ August, 2011.

Office for National Statistics. 2011b. Deaths from C. difficile in England and Wales. http://www.statistics.gov.uk/cci/nugget.asp?id=1735 C.diff. Accessed $15^{\text {th }}$ August, 2011. 
Oliver, J.D., Hite, F., McDougald, D., Andon, N.L., Simpson, L.M., 1995. Entry into, and resuscitation from, the viable but nonculturable state by Vibrio vulnificus in an estuarine environment. Appl. Env. Microbiol., 61, 2624-2630.

Oliver, J.D., 2010. Recent findings on the viable but nonculturable state in pathogenic bacteria. FEMS Microbiol. Rev. 34, 415-425.

Parsons, H.M., 1974. What happened at Hawthorne. Science 183, 922-932.

Peacock, J.E., Marsik, F.J., Wenzel, R.P., 1980. Methicillin-resistant Staphylococcus aureus - introduction and spread within a hospital. Ann. Int. Med., 93, 526-532.

Pérez-Rodríguez, F., Valero, A., Carrasco, E., García, R.M., Zurera, G., 2008. Understanding and modelling bacterial transfers to foods: a review. Trends Food Sci., $19,131-144$.

Pinto, F., Hiom, S., Girdlestone, S., Maillard, J.Y., 2009. Evaluation of the effectiveness of commercially available contact plates for monitoring microbial environments. Lett. Appl. Microbiol., 48, 379-82.

Pittet, D., Allegranzi, B., Sax, H., Bertinato, L., Concia, E., Cookson, B., Fabry, J., Richet, H., Philip, P., Spencer, R.C., Ganter, B.W.K., Lazzari, S. 2005.

Considerations for a WHO European strategy on health-care-associated infection, surveillance, and control. Lancet Infec. Dis., 5, 242-250.

Poulis, J.A., De Pipijper, M., Mossel, D.A.A., Dekkers, P.P.A., 1993. Assessment of cleaning and disinfection in the food-industry with the rapid atp-bioluminescence technique combined with the tissue-fluid contamination test and a conventional microbiological method. Int. J. Food Microbiol., 20, 109-116. 
Pratt, R.J., Pellowe, C.M., Wilson, J.A., Loveday, H.P., Harper, P.J., Jones, S.R.L.J., McDougall, C., Wilcox, M.H., 2007. epic 2: National evidence-based guidelines for preventing health-care associated infections in NHS hospitals in England, J. Hosp. Infect., 65S, S1-S64.

Prevost, D., Angers, D.A., Nadeau, P. 1991. Determination of ATP in soils by highperformance liquid-chromatography. Soil Sci. Biochem., 23, 1143-1146.

Probst, A., Facius, R., Wirth, R., Wolf, M., Moissl-Eichinger, C., 2011. Recovery of Bacillus spore contaminants from rough surfaces: a challenge to space mission cleanliness control. Appl. Env. Microbiol., 77, 1628-37.

Rahman, M., 1998. Learning to live with MRSA. Postgrad. Med. J., 74, 385-386.

Reardon, C. W. I., Brown, T. P. L. H., Stephenson, A. J., Freedlander, E., 1998. Methicillin-resistant Staphylococcus aureus in burns patients - why all the fuss? Infect. Control, 24, 393-397.

Redsven, I., Kymalainen, H.R., Pesonen-Leinonen, E., Kuisma, R., Ojala-Paloposki, T., Hautala, M. Sjoberg, A.M., 2007. Evaluation of a bioluminescence method, contact angle measurements and topography for testing the cleanability of plastic surfaces under laboratory conditions. Appl. Surf. Sci. 253, 5536-5543.

Rose, L., Jensen, B., Peterson, A., Banerjee, S.N., Srduino, M.J., 2004. Swab materials and Bacillus anthracis spore recovery from nonporous surfaces. Emerg. Infect. Dis., 10, 1023-1029. 
Schneider, D.A, Gourse, R.L., 2004. Relationship between growth rate and ATP concentration in Escherichia coli: a bioassay for available cellular ATP. J. Biol. Chem., 279, 8262-8268.

Schuerger, A.C., Fajardo-Cavazos, P., Clausen, C.A., Moores, J.E., Smith, P.H., Nicholson, W.L., 2008. Slow degradation of ATP in simulated Martian environments suggests long residence times for the biosignature molecule on spacecraft surfaces on Mars. Icarus, 194, 86-100.

Seeger, K. and Grffiths, M.W., 1994, ATP bioluminescence for hygiene monitoring in healthcare institutions. J. Food Prot., 57: 509-512

Setlow, P., Kornberg, A., 1970. Biochemical studies of bacterial sporulation and germination. XXIII Nucleotide metabolism during spore germination. J. Biol. Chem., $245,3645-3652$.

Sherertz, R.J., Bassetti, S., Bassetti-Wyss, B. 2001."Cloud" health-care workers. Emerg. Infect. Dis., 7, 241-244.

Siragusa, G.R., Cutter, C.N., Dorsa, W.J., Koohmaraie, M., 1995. Use of a rapid microbial ATP bioluminescence assay to detect contamination on beef and pork carcasses. J. Food Prot. 58, 770-775.

Stanley, P.E., 1986. Extraction of adenosine-triphosphate from microbial and somatic-cells. Meth. Enzymol. 133, 14-22.

Tekerekoglu, M.S., Duman, Y., Serindag, A., Cuglan, S.S., Kaysadu, H., Tunc, E., Yakupogullari, Y., 2011. Do mobile phones of patients, companions and visitors carry multidrug-resistant hospital pathogens? Amer. J. Infect. Control, 39, 379-381. 
Tifft, E.C., Spiegel, S.J., 1976. Use of adenosine triphosphate assay in disinfection control. Env. Sci. Technol., 10, 1268-1272.

Turner, D.E., Daugherity, E.K., Altier, C., Maurer, K.J., 2010. Efficacy and limitations of an ATP-based monitoring system. J. Amer. Assoc. Lab. Animal Sci., 49, 190-195.

Ukuku, D.O., Sapers, G.M., Fett, W.F., 2005. ATP bioluminescence assay for estimation of microbial populations of fresh-cut melon. J. Food Prot., 68, 2427-2432.

Van Dyke, K., Stitzel, R, McLella, T., Szustkie, C., 1969. An automated procedure for sensitive and specific determination of ATP. Clin. Chem., 15, 3-14.

Vartoukian, S.R., Palmer, R.M., Wade, W.G., 2010. Strategies for culture of "unculturable" bacteria. FEMS Microbiol. Lett., 309, 1-7.

Velazquez, M., Feirtag, J.M., 1997. Quenching and enhancement effects of ATP extractants, cleansers and sanitizers on the detection of the ATP bioluminescence signal J. Food Prot., 60, 799-803.

Venkateswaran, K., Hattori, N., La Duc, M.T., Kern, R., 2003. ATP as a biomarker of viable microorganisms in clean-room facilities. J. Microbiol. Meth., 52, 367-377.

Wadhawan, T., McEvoy, J., Prüß, B.M., Khan, E., 2010. Assessing tetrazolium and ATP assays for rapid in situ viability quantification of bacterial cells entrapped in hydrogel beads. Enz. Microbial Technol., 47, 166-173.

Washer, P., Joffe, H., 2006. The "hospital superbug": social representations of MRSA. Social Sci. Med., 63, 2141-2152. 
Weber, D.J., Rutala, W.A., 2011. The role of the environment in transmission of Clostridium difficile infection in healthcare facilities. Infect. Contr. Hosp. Epidemiol., 32, 207-209.

Webster, W.R., Lee, J.Y., Deininger, R.A., 2005. Rapid assessment of microbial hazards in metalworking fluids. J. Occup. Env. Health, 2, 213-218.

Werlein, H.D., 2001. Comparison of destructively and rinsing gained samples to determine TVC of pig carcasses by bioluminescence. Meat Sci., 59, 165-168.

Whitehead, K., Verran, J., 2006. The effect of surface topography on the retention of microorganisms. Food Bioprod. Proc., 84, 253-259.

Willis, C., Morley, R., Westbury, J., Greenwood, M., Pallett, A., 2007. Br. J. Infect. Control, 8, 17-21.

Wilson, C.A., Stevenson, H., Chrzanowski, T.H., 1981. The contribution of bacteria to the total adenosine triphosphate extracted from the microbiota in the water of a salt-marsh creek. J. Exp. Mar. Biol. Ecol., 50, 183-195.

Woodling, S.E., Moraru, C., 2005. Influence of surface topography on the effectiveness of pulsed light treatment for the inactivation of Listeria innocua on stainless-steel surfaces. J Food Sci., 70, M345-M351. 


\section{Figure captions}

Figure 1. Scatter plot of Bioluminescence and TVC data obtained from a number of different sites (over-bed tables, armchairs, floors, bedside lockers, wall rails, window sills, toilet seats) in a hospital ward. Coefficient of variation $\left(R^{2}\right)=0.078$.

Figure 2. Stages in an Integrated Cleaning Programme (Redrawn from Griffith et al., 2000).

\section{Table captions}

Table 1. Correlations of ATP with microbial counts expressed as colony forming units (CFU).

Table 2. The ATP content of cells. 


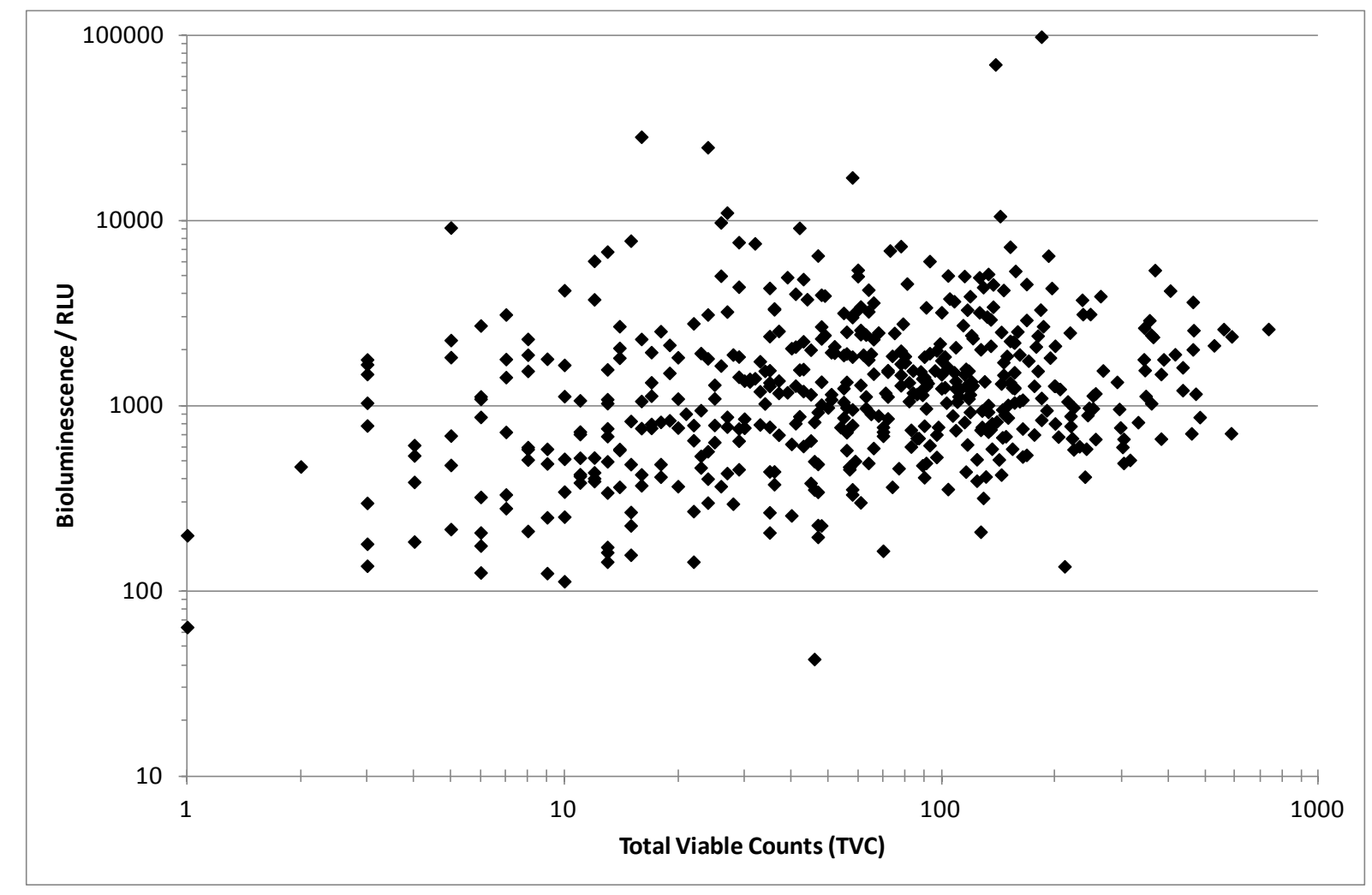

Figure 1. Scatter plot of Bioluminescence and TVC data obtained from a number of different sites (over-bed tables, armchairs, floors, bedside lockers, wall rails, window sills, toilet seats) in a hospital ward. Coefficient of variation $\left(R^{2}\right)=0.078$. 


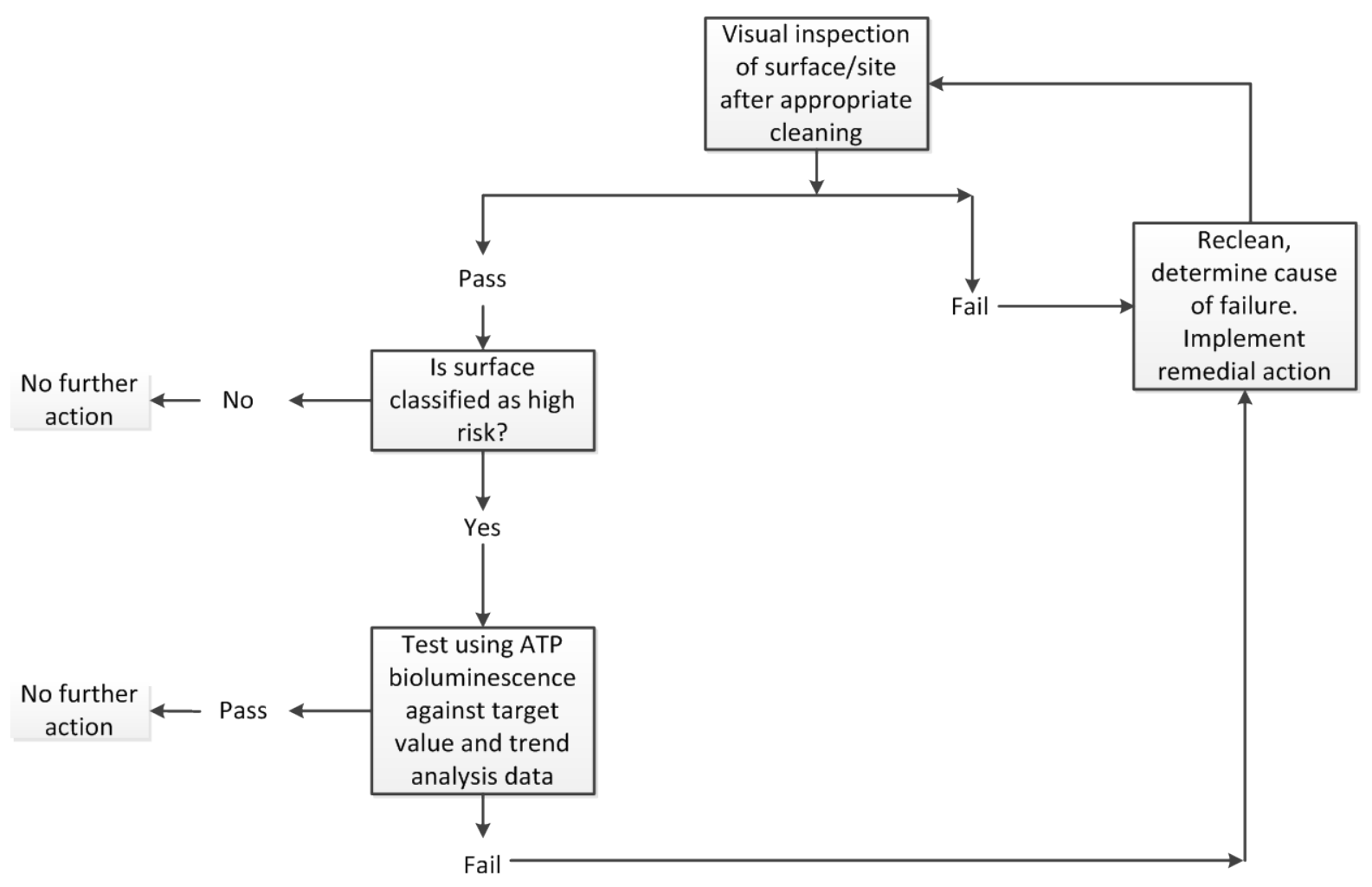

Figure 2. Stages in an Integrated Cleaning Programme (Redrawn from Griffith et al., 2000). 


\begin{tabular}{|l|l|l|}
\hline Application & $\begin{array}{l}\text { Coefficient of } \\
\text { Variation } \mathbf{R}^{2} \text { ) }\end{array}$ & Reference \\
\hline $\begin{array}{l}\text { E. coli entrapped in } \\
\text { hydrogel beads }\end{array}$ & $0.96-0.99$ & $\begin{array}{l}\text { Wadhawan et al. } \\
(2010)\end{array}$ \\
\hline Melon & $0.95-0.99$ & Ukuku et al. (2005) \\
\hline $\begin{array}{l}\text { E. coli \& } \\
\text { Staphylococcus in } \\
\text { beef broth }\end{array}$ & 0.93 & Luo et al (2009) \\
\hline Animal carcasses & $\begin{array}{l}\text { Beef } 0.92 \\
\text { Pork 0.93 }\end{array}$ & Siragusa et al. (1995) \\
\hline Pork carcasses & 0.87 & Werlein (2001) \\
\hline Metalworking fluids & $0.74-0.89$ & Webster et al. (2005) \\
\hline $\begin{array}{l}\text { Domestic } \\
\text { refrigerators }\end{array}$ & $0.82-0.85$ & $\begin{array}{l}\text { Chen and Godwin } \\
\text { (2006) }\end{array}$ \\
\hline Natural waters & 0.80 & (Hammes et al., 2010) \\
\hline Raw milk & 0.77 & Bell et al. (1996) \\
\hline $\begin{array}{l}\text { Disinfected } \\
\text { wastewater }\end{array}$ & 0.76 & Tifft and Spiegel (1976) \\
\hline Maple syrup & 0.73 & Lagace et al. (2002) \\
\hline $\begin{array}{l}\text { Neck skin of } \\
\text { chickens }\end{array}$ & 0.72 & $\begin{array}{l}\text { Ellerbroek and Lox } \\
\text { (2004) }\end{array}$ \\
\hline Cows' udders & 0.64 & Finger \& Sischo (2001) \\
\hline
\end{tabular}

Table 1. Correlations of ATP with microbial counts expressed as colony forming units (CFU). 


\begin{tabular}{|c|c|c|c|}
\hline Organism & Source & $\begin{array}{l}\text { ATP (Moles) per } \\
\text { cell }\end{array}$ & Reference \\
\hline \multirow{14}{*}{ Bacteria } & $\begin{array}{l}\text { Natural marine } \\
\text { environments }\end{array}$ & $9.4 \times 10^{-19}$ to $1.3^{-1 /}$ & $\begin{array}{l}\text { Calculated from the } \\
\text { data of Holm-Hansen } \\
\text { (1973) }\end{array}$ \\
\hline & $\begin{array}{l}\text { Laboratory grown } \\
\text { Serratia sp. }\end{array}$ & $\begin{array}{l}9.9 \times 10^{-19} \text { to } 2.8 \times \\
10^{-18}\end{array}$ & Holm-Hansen (1973) \\
\hline & $\begin{array}{l}\text { Various -Data } \\
\text { compilation for } 22 \\
\text { different bacterial } \\
\text { species }\end{array}$ & $\begin{array}{l}5.6 \times 10^{-20} \text { to } 9.7 \times \\
10^{-18}\end{array}$ & $\begin{array}{l}\text { Tifft and Spiegel } \\
(1976)\end{array}$ \\
\hline & $\begin{array}{l}\text { Unspecified } \\
\text { laboratory-grown } \\
\text { species } \\
\text { Natural microbiota of } \\
\text { salt marshes }\end{array}$ & $\begin{array}{l}2.9 \times 10^{-18} \\
4.7 \times 10^{-21} \text { to } 5.6 \times \\
10^{-19}\end{array}$ & Wilson (1981) \\
\hline & $\begin{array}{l}\text { Laboratory-grown } \\
\text { Pseudomonas } \\
\text { paucimobilis }\end{array}$ & $\begin{array}{l}3.2 \times 10^{-19} \text { to } \\
4.4 \times 10^{-18}\end{array}$ & $\begin{array}{l}\text { Fairbanks et al. } \\
(1984)\end{array}$ \\
\hline & $\begin{array}{l}\text { Not specified- } \\
\text { average value }\end{array}$ & $2.0 \times 10^{-19}$ & Stanley (1984) \\
\hline & $\begin{array}{l}\text { Campylobacter jejuni } \\
\text { E. coli }\end{array}$ & $\begin{array}{l}3.4 \times 10^{-18} \text { to } 4.1 \times \\
10^{-18}\end{array}$ & Ng et al. (1985) \\
\hline & $\begin{array}{l}\text { Clean Rooms } \\
\text { 'Ordinary Rooms' }\end{array}$ & $\begin{array}{l}2.5 \times 10^{-15} \\
0.3 \times 10^{-15}\end{array}$ & $\begin{array}{l}\text { Venkateswaran et al. } \\
\text { (2003) }\end{array}$ \\
\hline & $\begin{array}{l}\text { Laboratory-grown } \\
\text { Listeria } \\
\text { monocytogenes }\end{array}$ & $3.4 \times 10^{-21}$ & Li et al. (2003) \\
\hline & Not stated & $\begin{array}{l}2.0 \times 10^{-19} \text { to } 4.4 \times \\
10^{-18}\end{array}$ & $\begin{array}{l}\text { Cowan and } \\
\text { Casanueva (2007) }\end{array}$ \\
\hline & Not stated & $2.0 \times 10^{-19}$ & Redsven (2007) \\
\hline & $\begin{array}{l}\text { Natural aquatic } \\
\text { environments }\end{array}$ & $1.0 \times 10^{-19}$ & $\begin{array}{l}\text { Hammes et al. } \\
(2010)\end{array}$ \\
\hline & $\begin{array}{l}\text { Laboratory-grown } \\
\text { Mycobacterium } \\
\text { tuberculosis }\end{array}$ & 0.6 to $3.4 \times 10^{-18}$ & $\begin{array}{l}\text { Gengenbacher et al. } \\
(2010)\end{array}$ \\
\hline & Not stated & $2.0 \times 10^{-18}$ & Aiken et al. (2011) \\
\hline Bacterial Spores & Not stated & $1.0 \times 10^{-21}$ & $\begin{array}{l}\text { Cited in } \\
\text { Venkateswaran et al. } \\
(2003)\end{array}$ \\
\hline \multirow[t]{3}{*}{ Yeast } & $\begin{array}{l}\text { Laboratory-grown } \\
\text { Saccharomyces } \\
\text { cerevisiae }\end{array}$ & $1.4 \times 10^{-23}$ & $\begin{array}{l}\text { Autio \& Mattila- } \\
\text { Sandholm (1992) }\end{array}$ \\
\hline & $\begin{array}{l}\text { Laboratory-grown } \\
\text { Saccharomyces } \\
\text { cerevisiae }\end{array}$ & $4.4 \times 10^{-17}$ & Guillou (2003) \\
\hline & Not stated & $2.0 \times 10^{-17}$ & Redsven (2007) \\
\hline Fungal Spores & $\begin{array}{l}\text { Laboratory-grown } \\
\text { Paecilomyces } \\
\text { farinosus }\end{array}$ & $3.0 \times 10^{-16}$ & Lane et al. (1988) \\
\hline
\end{tabular}

Table 2. The ATP content of cells. 
